\title{
ТРАДИЦЙНИЙ ФОЛЬКЛОРНИЙ ОБРАЗ МОСКАЛЯ: СОЦІАЛЬНО-ПСИХОЛОГІЧНІ ПАРАМЕТРИ
}

Мельник Н. Г. Традиційний фольклорний образ москаля: соціальнопсихологічні параметри.

У статті досліджується традиційний фольклорний образ москаля. Його трактування продиктоване історичними, політичними, психологічними чинниками української історії. здебільшого цей образ постає у фольклорі у двох соціальнопсихологічних варіантах. Це москаль-солдат (вояк російської армії, можливо, українець за походженням) та москаль - росіянин за походженням. У народних оцінках цих фольклорних типів є певні відмінності.

Ключові слова: фольклор, москаль, солдат, морально-етичні принципи. 
Мельник Н. Г. Традиционный фольклорный образ москаля: социальнопсихологические параметры.

В статье исследуется традиционный образ москаля. Его трактовка продиктована историческими, политическими, психологическими особенностями украинской истории. Как правило, этот образ представлен в фольклоре двумя социально-психологическими вариантами. Это москаль-солдат (воин русской армии, возможно, украинец по происхождению) и москаль - русский. В народных оценках этих фольклорных типов есть некоторые различия.

Ключевые слова: фольклор, москаль, солдат, морально-этические принципы.

Melnyk N. G. Traditional folklore image of Moskal: social and psychological characteristics.

The article investigates a traditional folk image of Moskal as a social and psychological type. Its interpretation is determined by various historical, political, psychological factors in terms of the history of Ukraine. As a rule, this image is represented in the folklore in two social and psychological ways. This Moscovite soldier (Russian soldier, sometimes Ukrainian by origin forced to serve foreign political interests) and Moskal, who is Russian by birth, but penetrating in the Ukrainian society after the well known events. There are certain differences in folk's assessments of these two types.

Thus, the attitude to the first type is connected and mostly influenced by national understanding of human dependence on unfair circumstances and considering historical background. This refers to the phenomenon of compulsory recruitment and military service, which was performed after Zaporizhian Sich destruction. Moscovite soldier of the first type, according to the folk understanding is an unhappy faithless, doomed to constant hardships person. Often Moscovite (former countryman) is perceived as immoral man, that is why it is better to handle carefully with such people. The second type (Moskal, who is Russian by birth) is usually interpreted by folk consciousness in the categories "another", "alien". This Moskal is an enemy against whom Cossacks are constantly fighting (mean, treacherous and cunning). This Moskal is a commander of the royal army or a Moscovite soldier, who stays at a peasant family. Usually they are negatively labeled in the folk consciousness.

This paper emphasizes that the interpretation of the Moskal image in folklore is not the evidence of Ukrainian national intolerance but the result of deep person's behavior analyzing, his acting as a representative of a particular social stratum, which is caused by social and psychological factors. Our people have always been open to a dialogue, creative collaboration and sharing traditions. However, Ukrainians rightly demand respect in return to their culture, abhor violence, arrogance, deception, trimmering. These national concepts should be looked as the sources of national treating to Moskal soldier and vividly represented in folklore.

Key words: folklore, Moscovite soldier, moral and ethical principles.

Проблема дослідження національного менталітету - одна 3 найактуальніших у сучасному глобалізаційному просторі. Осмислення народом своєї оригінальності, специфічності, усвідомлення відмінностей між власними життєвими орієнтирами та принципами 
життя представників інших націй надзвичайно важливі, адже дають змогу визначити провідну національну ідею, історичну місію, шлях до майбутнього прогресивного розвитку.

Як справедливо зазначає X. Кук у дослідженні «Національний менталітет в умовах трансформації сучасного українського суспільства», «національний менталітет - це сукупність історично сформованих установок і рис характеру народу, цінностей, стереотипів i архетипів, які мають специфіку поведінкового прояву <...>. Національний менталітет проявляється як сукупність внутрішніх настанов, нахилів народу щодо характеру їх діяльності, мислення, відчуття та сприйняття світу саме тільки йому притаманним чином. Національний менталітет має конкретно-історичний характер, відповідає певним періодам розвитку суспільства, визначає стереотипні уявлення до навколишнього світу та забезпечує можливість адаптації до нього людини» [6, с. 8-9].

На думку Г. Гачева, автора книги «Національні образи світу», «особливо гостро проблема національного розуміння постала у XX столітті. Тут парадокс: 3 одного боку народи світу максимально наближаються один до одного за способом життя, побутом, виробництвом, культурою, а 3 іншого, - загострюється національна чутливість. Дивно? Але вже з історії розвитку національних почуттів видно, що справа не різкості відмінностей, а в частоті контактів: < ..> якщо вони жодного разу не зустрічалися, то й не знають про інших і про свої особливості. Але навіть близнюки в родині - як різко різні індивідуальності відчуваються. Так що єдиний діалектичний процес асиміляції-дисиміляції народів та національних культур відбувається і в наш час» [3].

Стосунки Україна / Росія - особлива сторінка нашої історії, що на тлі сьогодення зазнає гострих дискусій. В. Брехуненко так діагностує сучасний стан проблеми: «Спільне минуле», «тісне переплетення історичних доль», «глибоке усвідомлення нерозривної єдності» - подібні пафосні епітети не втомлюються прикладати до історії українсько- 
російських стосунків московські політики та й більшість інтелектуалів. Не відстає й частина української верхівки , вражена хронічним вірусом меншовартості. Насправді ж подібні голосні заяви не витримують навіть елементарної перевірки на історичному матеріалі» [1, с. 9]. На думку історика, «московська експансія, яка розпочалася 3 кінця XV ст. , до сьогодні визначає єство українсько-російських узаємин. Ї̈ї похідними $є$ заперечення самобутності українського етносу, подання його як частини «русского мира» та прагнення стерти з лиця землі все українське шляхом цілковитого зросійщення українців» [1, с. 9]. Протягом розвитку історії стосунків Україна / Росія наш народ уважно стежить за подіями, глибоко аналізує внутрішні та зовнішні вияви цих зв'язків, виявляючи своє ставлення до них. Результати такого народного аналізу можна побачити, звернувшись до фольклорного образу москаля.

Найяскравіше народні оцінки виявляються в таких жанрах фольклору, як прислів'я та приказки, соціально-побутові пісні й соціально-побутові казки. Слід зазначити, що в запропонованій студії ми звертаємося до фольклорних зразків, що виникають протягом XVII-XIX ст. Фольклор XX століття - окрема сторінка в осмисленні народом образу москаля. Перебування українців у складі радянської тоталітарної держави зумовило появу нових художніх модифікацій образу москаля. Тому, на нашу думку, ця тема заслуговує окремого дослідження.

Образ москаля в українській народній творчості названого періоду - складний і неоднозначний. Його трактування продиктоване історичними, політичними, психологічними чинниками української історії. Здебільшого цей образ постає у фольклорі в двох соціальнопсихологічних варіантах. Це москаль-солдат (українець - вояк російської армії) та москаль-росіянин, представник українського суспільства після відомих подій. У народних оцінках цих фольклорних типів є певні відмінності.

Так, ставлення до першого типу продиктоване народним розумінням залежності людини від обставин, усвідомленням 
об’єктивності ситуації, що склалася історично. Ідеться про явища рекрутчини та солдатчини, запроваджені після зруйнування Запорізької Січі. Вони репрезентовані в народній пам'яті багатоманітністю мотивів, образів, сюжетів, що й зумовило виникнення цілого пласту народної творчості - творів солдатської та рекрутської тематики. Москаль-солдат першого типу, за народним розумінням, - нещасна, бездольна, приречена на вічні злигодні людина. Мотиви соціально-побутової лірики солдатської тематики переважно трагічні. Військове середовище царської армії для чоловіка - чуже і неприродне:

Ой зірву я три листочки

3 зеленого барвіночку, зеленого барвіночку.

Один зірву та й заграю:

Щастя-долі я не маю.

Другий зірву та й заграю:

До прийому іти маю...

Третій зірву та й заграю:

3 москалями жити маю...

Ой як тяжко камінь гризти,

Так тяженько в війську жити (7, с. 165).

Ідучи до російського війська, парубок розуміє, що, можливо, навіки прощається з родиною:

Государське плаття взявши, навіки загину.

Ой загину, моя мати, загину,

Вже свою родиночку навіки покину (7, с. 196);

«В тебе роду вже нема,

Батько й мати померла < .. >

Сестра заміж пішла.

Та остався один брат,

Та й той ходии не жонат».

«Oй тоді я оженюсь,

Як на лавичі положусь<...>» $(7$, с. 171). 
Зовнішній вигляд солдата - естетично неприйнятний для носія традиційної культури, адже символізує втрату людиною особистої свободи, ії примус до неприродної діяльності:

Оббреїли чорні кудрі

На золотім гребінщі.

Оббреїли чорні кудрі

У суботу враниі,

Наділи на того сироту

Ще й московські ранизі (7, с. 180).

Народ тонко відчуває психологічні зміни, що відбуваються 3 людиною, яка змушена виживати в чужому неприродному оточенні. Тому образ москаля-солдата осмислюється як уособлення людини, яка згрубіла у війську, утратила зв'язки 3 національним, родинним оточенням, отже, і з морально-етичними орієнтирами свого етнічного середовища. Часто москаль (колишній земляк) сприймається як аморальна людина. Тому з ним слід поводитися обережно.

Крім того, навіть якщо він повернувся зі служби відносно здоровим фізично і морально, він зазвичай уже не має трудових навичок, притаманних селянинові, i не зможе пристосуватися до нормального життя:

Дурна дівка, нерозумна,

На солдата уповала,

На солдатськую худобу!

А в солдата ні худоби,

Тільки в його три торби:

Перва торба - із пшоном , із сіллю,

А другая - з сухарями,

Манірка-з водою!

Живе дівка із бідою

За солдатською головою!(7, с. 222).

Другий тип (москаль, що $є$ росіянином за походженням) осмислюється здебільшого фольклорною свідомістю через категорії 
«інший», «чужий». При всій толерантності, притаманній нашому народові, терпимості щодо інших націй, українці постійно відчували цю «іншість». В. Брехуненко зазначає: «Увесь час українці демострували, що сприймають московитів / росіян як цілковито «інших», а Московію / Росію як чужу незвідану планету. Особливо це стало помітно після Переяславської ради 1654 р., коли доти епізодичні контакти переросли в тісніші стосунки і вже не тільки вище православне духівництво та частина козаків, а й ширший загал українського суспільства отримав змогу роздивитися московитів зблизька. Принесло це мало втіхи. Переяслав 1654 р., який з погляду Б. Хмельницького був суто тактичним кроком, призначеним використати Москву для остаточної перемоги над Річчю Посполитою, а також для міжнародного визнання відновленої Української держави та iї правителя-гетьмана, став не відправним пунктом зближення, а каталізатором взаємного несприйняття, війн і трагедій [1, с. 9-10].

Цей фольклорний образ москаля представлено багатоманітністю варіантів. Це москаль-ворог, з яким воюють козаки (хитрий, зрадливий $\mathrm{i}$ підступний); це москаль-командир у царській арміі та москаль-солдат, що квартирує в селянській родині. Вони марковані підкреслено негативно. Народне ставлення до москаля яскраво репрезентоване у прислів'ях та приказках: 1) москаль-ворог, «чужий»: Москаль казенна річ (9, с. 76); Від москаля поли вріж та тікай (9, с. 76); 3 салдатом - не своїм братом, не стягайся $(9$, с. 76); Москаль не свій брат, не пожалує (9, с. 76); 3 Москалем дружи, а камінь за пазухою держи (9, с. 76); Cтарість не радість, а Москаль не брат (9, с. 708); Москаль і Лях один шеляг (9, с. 697); 2) москаль як людина, що може вкрасти, збрехати, любить пожити за рахунок інших: Москалики, соколики, позіїдали ви намі волики, а як вернетесь здорови, то поїсте и корови (9, с. 76); Для того і вуланчики, щоб запірала чуланчики (9, с. 76); Мабуть москаль тоді красти перестане, як чорт молиться Богу стане $(9$, с. 77); На вовка помовка, а москаль кобилу вкрав (9, с. 77); Коли москаль каже сухо, то піднімайся по вухо (9, с. 77); Москаль тоді () Н. Г. Мельник, 2016. 
правду скаже, як чорт молицьия стане ((9, с. 77); Казав москаль право, та й збрехав браво (9, с. 77); У йому стільки віри, як в москалеві правди (9, с. 708); 3) москаль, який зверхньо ставиться до інших: На грош амуниції, на десять амбииї $(9$, с. 77); Москаль ликом чванищчия й кожному під ніс з ним пхаєция $(9$, с. 8$)$.

Цікаво, що прислів'я та приказки як жанр, що вирізняється лаконічністю та місткістю, репрезентує категоричність народних оцінок щодо морально-етичних рис москаля. Інші ж жанри ілюструють більш обережне ставлення до цього соціальнопсихологічного типу. Так, аналізуючи зміст «народної» частини вертепу, О. Воропай зазначає: «Як відомо, у XVIII-му столітті, а особливо після поразки під Полтавою року 1709, на Україні були «постої» російських військ, що дуже допікали нашому населенню. Хоч населення москалями було незадоволене, усе ж у Сокиренському вертепі ми не зустрічаємо такого гостро негативного ставлення персонажів до москаля, як до поляка. Це, очевидно, тому, що москалі, як окупанти України, могли контролювати публічні виступи. Крім того, відігравали тут певну ролю і віросповідні мотиви» [2, с. 85].

Таку ж обережність демонструє соціально-побутова казка, що містить великий масив творів про хитрого й винахідливого солдата. Так, у казці «Як солдат із зуба борони юшку варив» розповідається про те, як москаль-солдат виманює в баби необхідні продукти для того, аби зготувати юшку. Пообіцявши, що зварить іiі з зуба борони, солдат поступово додає до страви бабину сіль, пшоно, картоплю та цибулю. Народ пояснює таку поведінку досить просто: «Солдатики хитрі на всякі видумки, бо голод не тітка» [10, с. 598]. У казці «Солдат борщ солить», крім хитрості, народ наділяє солдата такими рисами, як вередливість та непорядність:

Прийшов солдат на квартиру, дає йому баба борщ, він і почав вередувати.

- Що у тебе, бабко, борщз несолоний!

- Та ось, служивий, зараз пошукаю солі. 
- Тільки одвернулась, він дістав з кишені солі та й посолив, аж ось $і$ баба приносе.

- Не треба, - каже, я уже посолив.

- Чим? - пита.

- Та ие у мене така ложка.

-Продай-бо, мені ї̈.

- Давай сто рублів... (4, с. 292).

Казка «Солдат та сповіді» репрезентує образ москаля-солдата як аморальної людини, яка не має в душу нічого святого: Cnовідається солдат і чує, щз у батюшки часи дзеленькають. Він взяв та й украв їх (4, c. 291).

Таке трактування образу москаля у фольклорі не є свідченням національної нетерпимості українців, це результат глибокого аналізу поведінки людини-представника певного суспільного прошарку, що зумовлена соціально-психологічними чинниками. Ми погоджуємося 3 думкою Г. Гачева: «Багатовіріантність народів та їх культур - це скарб людства. Подібно до того, як у симфонічному оркестрі кожний інструмент має свій тембр, так і кожний народ наділений особливим талантом бачити світ i творити речі таким чином, який не притаманний народові-сусідові. <..> народи на планеті доповнюють один одного і нам необхідно не просто мати терпимість, толерантність до відмінностей між народами та їх культурами, але відчувати до них любов так само, як ми поважаємо розподіл праці у виробництві [3].

Наш народ завжди був і $є$ відкритим для спілкування, обміну традиціями, творчої співпраці. Водночас він справедливо вимагає поваги до себе, своєї культури, не терпить насильства, зверхності, хитрості, пристосуванства. Саме в цій національній концепції слід шукати витоки народного ставлення до москаля-солдата, що яскраво репрезентовані в фольклорі.

\section{Література}

1. Брехуненко В. «Братня» навала. Війна Росії проти України XII-XXI ст. /
В. Брехуненко,
В. Ковальчук,
М. Ковальчук,
В. Корнієнко. - К., 2016. - 248 c.

С Н. Г. Мельник, 2016. 
2. Воропай О. Звичаї нашого народу [Етнографічний нарис] / О. Воропай. - К. : Оберіг, 1993. -600 c.

3. Гачев Г. Лебединая песня национальных культур. У них впереди не жизнь, а смерть : [стенограмма лекции] [Электронный ресурс] / Г. Гачев. - Режим доступу : http://polit.ru/article/2007/05/24/kulturosob.

4. Калинова сопілка. Антологія української народної творчості. Казки, анекдоти, легенди, перекази, оповідання [упорядкув., пер., ст. та прим. О.Ю.Бріциної, Г. В. Довженок, С. В. Мишанича]. - К. : Веселка, 1989. - 615 с.

5. Костомаров Н. И. Две русские народности / Н. И. Костомаров. - К.-Х. : Майдан, 1991. $-72 \mathrm{c}$.

6. Кук. Х. Т. Національний менталітет в умовах трансформації сучасного українського суспільства : автореф. дис. ... канд. філос. наук / Х. Т. Кук. - Одеса, 2012 - 19 с.

7. Соціально-побутові пісні [упорядкув. і пер. О. М. Хмілевської]. - К. : Дніпро, 1985. - $331 \mathrm{c}$.

8. Поплавська Т. М. Генезис менталітету особистості в національній культурі : автореф. дис. ... канд. філос. наук / Т. М. Поплавська. - Одеса, 1996. - 22 с.

9. Українські приказки, прислів'я і таке інше. Уклав М. Номис [упорядкув., прим. та вступна ст. М. М. Пазяка]. - К. : Либідь, 1993. - 768 с.

10. Українські народні казки. - К. : Ірпінь, 1996. -656 с.

Стаття надійшла до редакиії 29.11.2016 p. 